This is the peer-reviewed version of the article:

Simić, N.; Jablanović, M. M.; Grbić, S. Why Teaching? A Validation of the Fit-Choice Scale in the Serbian Context. Journal of Education for Teaching 2021.

https://www.tandfonline.com/doi/abs/10.1080/02607476.2021.1958655?journalCode=cjet20

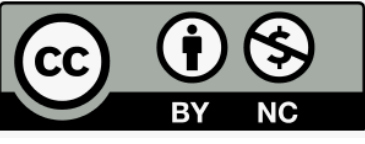

This work is licensed under the Creative Commons Attribution-NonCommercial 4.0 International license 


\section{Why teaching? A Validation of the Fit-Choice Scale in the Serbian Context}

Nataša Simića*, Milica Marušić Jablanovićb and Sanja Grbićab

${ }^{a}$ Faculty of Philosophy, University of Belgrade, Serbia

${ }^{b}$ Institute for Educational Research, Belgrade, Serbia

*Correspondence details: nsimic@f.bg.ac.rs, Čika-Ljubina 18-20, 11000 Belgrade, Serbia

\section{Biographical notes}

Nataša Simić, PhD, is a Senior Research Associate at the Institute of Psychology, Faculty of Philosophy, University of Belgrade, Serbia. Her main fields of expertise are teacher education, inclusive and multicultural education. She was one of the creators of the Master programme for subject teachers, initiated through the Tempus MASTS Project, and a teaching assistant at several University courses for both pre-service and in-service teachers.

Milica Marušić is a psychologist with PhD in Adult Education, engaged as a Research Associate at the Institute for Educational Research in Serbia. Her main fields of expertise are teacher education, scientific literacy and education for sustainable development. During doctoral studies she was granted a scholarship by the Greek Ministry of Education for conducting a comparative study of teacher education and professional development in Serbia and Greece. She was national coordinator for TIMSS 2015 for Serbia.

Sanja Grbić is a PhD student and a teaching assistant at the Department of Psychology, Faculty of Philosophy, University of Belgrade and research assistant at the Institute for Educational Research. Her research interests are at the intersection of educational, developmental and 
personality psychology and include topics of adolescent identity development, professional identity of teachers and narrative/discursive approach. 


\section{Why teaching? A Validation of the Fit-Choice Scale in the Serbian Context}

Abstract. The aim of this study was to validate the structure of the FIT-Choice scale on a Serbian sample of pre-service teachers, as well as to determine the motivations and beliefs about the teaching profession, and test if motivation differs across different groups of pre-service teachers. After prospective class and subject teachers $(\mathrm{N}=433)$ filled in the FIT-Choice scale, the CFAs were performed. For Motivations, the adjusted 12-factor model fits the data best. Ten original factors were replicated, and Bludging and Time for family appeared as separate factors, like in the first version of the FIT-Choice model, while Transferability and Security merged into one. The sixfactor Beliefs model with one item removed had the best fit indices. Intrinsic value, Social utility value and Perceived teaching ability were the highest rated motivations. Females and prospective class teachers were more motivated by altruistic motives and perceived the profession as more demanding than males and prospective subject teachers. The authors conclude that the FIT-Choice scale demonstrated acceptable structural and known-groups validity and reliability, and that the results on Motivations were similar to those obtained in Western countries.

Keywords: FIT-Choice; motivation; pre-service teachers; validation; Serbia

\section{Introduction}

Challenges related to the quality of teaching, teacher status, teacher shortages and turnover have led to a proliferation of studies addressing the topic of motivation for the teaching profession (Cooper and Alvarado 2006; Jeon and Wells 2018; Watt and Richardson, 2008). Nevertheless, the number of studies investigating teacher motivation for teaching has remained relatively low in south-eastern European countries like Serbia, which face many educational and 
socioeconomic challenges, such as a low level of functional literacy, a high level of brain drain and high unemployment rates (see e.g. Government of the Republic of Serbia 2018; KovácsCerović 2006; Stanković 2011; Videnović and Čaprić 2020). Serbia also has specific challenges around poor social status of the teaching profession, low teachers' salaries (European Commission/EACEA/Eurydice 2018; Nišević and Colić 2010; OECD 2013, 2014, 2016) and low interest from good candidates for a teaching career (Simić 2019). At the same time, due to a financial crisis and socio-political instability, numerous employment positions have been closed, which has made teaching positions more attractive, particularly among students educated to be class teachers and teachers of social science and humanities, who have few opportunities for employment elsewhere. On the other hand, teachers of Mathematics and Computer Science are lacking due to many other employment opportunities; however, the turnover of these teachers is more potential than real (Skočajić 2017).

Doing research on Serbian pre-service teachers' motivation for choosing a teaching career is also relevant because of the specific pattern of cultural values that are present in Serbian society, which may also be present in other countries with a similar socio-political background. Due to a prolonged post-socialist transformation (Lazić and Cvejić 2007), Serbia has both the characteristics of countries that are typically referred to as capitalist, individualistic Western countries and also those that are referred to as collectivistic, as well as those of Eastern countries in terms of cultural values (Hofstede, G., Hofstede, G. J., and Minkov 2005; Simić, Toković, and Đorđević 2019). Young people display a specific blend of cultural values and gender role expectations, with significant differences being found between urban and rural areas, and also between youth of different educational levels (Manić 2017). 
Few studies have compared different groups of teachers, such as males and females or those educated in different scientific disciplines, and they have yielded inconsistent results (e.g. Glutsch and König 2019; Kılınç, Watt, and Richardson 2012; Müller, Alliata, and Benninghof 2009). Seeking to fill these gaps and to shed light on potential culture-specific issues in research on (prospective) teachers, this study explores Serbian pre-service teacher motivation for the teaching profession using the well-established theoretical and methodological framework FITChoice (Richardson and Watt 2006; Watt and Richardson 2007).

\section{The Theoretical Framework and Previous Findings}

\subsection{Factors Influencing Teachers' Choice of the Teaching Profession}

Watt and Richardson (2008) developed the first comprehensive theoretical model of motivations for the teaching profession - Factors Influencing Teaching Choice (FIT-Choice) (see Figure 1), identifying 12 motivational constructs. It distinguishes two first order values - Personal utility, usually referred to as extrinsic motivation (includes Job security, Job transferability, Time for family) and Social utility, usually named altruistic motivation (includes Shape future of children/adolescents, Enhance social equity, Making social contribution, Work with children/ adolescents). Other motivational factors are: Intrinsic career value (refers to affinities towards teaching), Ability (perceptions of own abilities for teaching), Prior teaching and learning experiences, referring to one's own teachers and schooling experiences, Social influences significant others encouraging choice of teaching career and Fallback career-individuals who were unable to pursue their first-choice career (Watt \& Richardson 2012).

The model also includes "task perceptions such as demands (difficulty and required expertise) and return (social status and salary) related to certain aspects of a teaching career" 
(Jugović et al. 2012,272), named Task demand, Task return and Social dissuasion-

socialization influences where the individual is being discouraged to pursue a teaching career.

Finally, it measures satisfaction with the choice of teaching as a career, as an outcome variable.

\section{Insert Figure 1}

\subsection{Previous Findings}

On a large validation sample of Australian pre-service teachers (see Richardson and Watt 2006), 11 motivational factors were reproduced as theorised, while two factors merged into one (Bludging and Time for family) (Watt and Richardson 2007). The highest rated were Perceived teaching abilities, and the Intrinsic and Social utility value, while the lowest rated factor was Fallback career. Analyses of the perceptions and beliefs supported six rather than seven theorised underlying dimensions, with Social status and Teaching morale being merged into one (see Figure 1).

The subsequent studies mostly supported the FIT-Choice model. In some cultural contexts, Job transferability and Fallback career were not relevant or understood in the same way as in the original Australian context (Jugović et al. 2012; Watt et al. 2012), while in one study (Kılınç, Watt, and Richardson 2012), fewer motivation factors explained the data better (e.g. Shape future of children/adolescents, Make social contribution and Enhance social equity factor were combined into one). Teachers from Western European countries (Goller et al. 2019; Fokkens-Bruinsma and Canrinus 2012), USA (Lin et al. 2012), Australia (Watt et al. 2012) and Croatia (Marušić, Jugović, and Pavin Ivanec 2011) put emphasis on Intrinsic value and Social utility value over Personal utility value. In Turkey (Kılınç, Watt, and Richardson 2012) and China (Lin et al. 2012) the highest value factor proved to be Social utility, but Job security had 
prevalence over Intrinsic value. These studies reproduced all perception factors as theorized, and although they showed that preservice teachers rate the job demands as high, they also showed that they were satisfied with their career choice (Kılınç, Watt, and Richardson 2012; Lin et al. 2012; Marušić, Jugović, and Pavin Ivanec 2011; Watt et al. 2012.)

Several studies point to gender differences, suggesting that altruistic and, in some cases intrinsic motives, are stronger for female prospective teachers (K1lınç, Watt, and Richardson 2012, Müller, Alliata, and Benninghof 2009; Simić, Purić, and Stančić 2018). Although authors agreed that there are differences among teachers educated in different disciplines and belonging to different age groups, there are no common conclusions yet (see e.g. Glutsch and König 2019; Kılınç, Watt, and Richardson 2012; Müller, Alliata, and Benninghof 2009; Sinclair 2008).

\subsection{Present Study}

Despite the changes in legislation regarding the school system that Serbia underwent in recent years that produced new challenges for teaching professionals, and in spite of the unfavourable status of the teaching profession (e.g. European Commission/EACEA/Eurydice 2018; OECD 2014, 2016), the number of studies investigating teacher motivation in the Serbian context is relatively low (see e.g. Marušić and Oikonomou 2013; Marušić Jablanović 2014; Simić 2015; Simić, Bogdanović, and Jovanović 2013; Simić, Purić, and Stančić 2018). There were no studies that applied internationally validated instruments (except for one small-scale pilot study - see Marušić Jablanović and Vračar 2019), involving a larger sample of both class and subject preservice teachers and comparing different groups. Therefore, the aim of this study was twofold: a) to validate the structure of the FIT-Choice scale with a sample of pre-service class and subject teachers in Serbia; and b) to determine the motivations and beliefs about the teaching profession 
among Serbian pre-service teachers and test if motivation differs across different groups - males and females and teachers with different educational trajectories.

Although Serbian law requires both prospective class teachers (working with children aged 7-11) and subject teachers (working with children aged 12-18) to have a Master's degree and at least 36 ECTS of psychological, pedagogical and subject didactical courses and school practice since 2009, their educational trajectories significantly differ. When entering university, prospective class teachers choose a teaching career, and are integrally prepared for both teaching and the subjects. Subject teachers choose a teaching career at different points, depending on the study program, and have fewer courses that prepare them for teaching, less teaching practice and more career options once they graduate. Due to different professionalization pathways of class and subject teachers, and previously reported differences between Science and Engineering and Social Science and Humanities teachers (Glutsch and König 2019; Kılınç, Watt, and Richardson 2012) we treated pre-service class teachers and two groups of pre-service subject teachers as separate groups.

\section{Method}

\subsection{Participants}

The data were initially collected from 450 pre-service teachers. We did not include the participants who reported that they had more than 240 days of teaching experience gained through engagement in schools as substitute teachers, given that such an engagement was longer than the mandatory internship time at any of the faculties and almost as long as the induction period in Serbia. Therefore, the motivation structure of those participants would reflect not only 
their dispositions and preparatory education, but their job experiences as well, making them significantly different from typical pre-service teachers and more like novice teachers. Focusing on pre-service teachers makes our results comparable to the results obtained in other cultures using FIT-choice (for example Kılınç, Watt, and Richardson 2012; Lin et al. 2012; Watt \& Richardson 2007). This left us with a total of 433 participants.

Aiming for a diverse sample that would enable generalizations, we recruited participants from 14 faculties from four Serbian state universities (Belgrade, Novi Sad, Niš and Kragujevac) that educate the vast majority of future teachers in Serbia. The sample included both prospective class teachers and prospective subject teachers. The prospective subject teachers were students educated in various disciplines (e.g. Chemistry, History, Engineering, Serbian language etc.) attending modules or courses necessary for getting teaching qualifications who we classified according to their main discipline - Science and Engineering, and Social Science and Humanities (see Table 1). Participants were in their third or higher year of study, with the average age of 22.6 (range 20-40) and the average GPA of 8.16/10.

The proportion of males and females in our sample (see Table 1) reflects the proportion from the entire population of Serbian pre-service and in-service teachers (Statistical Office of the Republic of Serbia, 2020). The variety of profiles we covered reflects the diversity of disciplines and faculties in Serbia where students can obtain teacher qualifications.

Insert Table 1

\subsection{Instruments and Variables}

The FIT-choice scale involves a 38-item Factors influencing choice of a teaching career scale.

Each item begins with the statement "I chose to become a teacher because..." and continues with 
the reasons for choosing a teaching career, which participants rate on the 7-point Likert type scale (1 standing for 'not at all important', 7 - for 'extremely important'). The item set consists of the previously described 12 motivational constructs. The scale reliability reaches .80 or above across diverse samples (Jugović et al. 2012; K1lınç, Watt, and Richardson 2012; Watt et al. 2012). The Fallback career scale demonstrated the lowest reliability coefficients across studies (ranging from .57 to .67) (Watt et al. 2012).

The 14-item Perceptions/Beliefs about teaching scale consists of four subscales reflecting task demand and return (Expert career, High demand, Social status, Salary), one subscale for Social dissuasion and one for Satisfaction with choice, again with 7-point Likert type scales (1 standing for 'not at all', and 7 - 'extremely'). The scale has good reliability, with the subscales Expert career, High demand and Social dissuasion showing somewhat lower coefficients in some cultures (Jugović et al. 2012; Kılınç, Watt, and Richardson 2012; Lin et al. 2012; Watt et al. 2012).

For the purposes of this study, a forward translation process for adapting the scale was applied. The FIT-choice scale was translated from English to Serbian language by a bilingual speaker and tested on six students from the relevant population, highly proficient in both languages. The meaning of each item was discussed, and translation was adjusted in order to improve clarity. The original and Serbian version were then compared, checking for matching in meaning and tolerating only minimal changes. For Social dissuasion and Satisfaction with choice subscales, instead of questions, the items were given in the form of statements, without altering the meaning (for example, the original item How carefully have you thought about becoming a teacher? was changed into I have thought carefully about becoming a teacher). The translation 
was then approved by a five-member team of educational scientists highly proficient in English (items are given in Tables A1 and A2 in Appendix A).

The final instrument was extended by adding questions regarding students' background (gender, age), educational trajectory and discipline, average grade - GPA, and previous teaching experience.

\subsection{Procedure}

The instruments were administered to the students during regular classes at their faculties. In the case of three faculties, the teachers asked the students to fill in the form online. The research was voluntary and anonymous, with a response rate of $91 \%$.

\subsection{Statistical Analyses}

Confirmatory factor analyses (CFAs) for Motivations and Beliefs were initially performed because a strongly theorised and previously empirically validated scale was applied. Prior to CFAs, missing values analysis was conducted, which showed that data were primarily missing due to item nonresponse. The percentage of missing values for both Motivation and Beliefs scales ranged from 0 to $0.9 \%$. Given that values were missing at random (Schafer and Graham 2002), Multiple imputation was performed in IBM SPSS Statistics for Windows, version 24.0, using the default option of five imputations. The CFAs were performed in Amos 24.0, with Maximum likelihood method applied to test the original 12-factor (Motivation) and 6-factor

(Beliefs) models, like in the validation study by Kılınç, Watt, and Richardson (2012). 
In order to determine if the measurement pattern of latent constructs remains invariant across different samples, we calculated configural (testing if the same items measure our constructs across groups), metric (testing for the group equivalency of the factor loadings) and scalar invariance (testing for the group equivalency of the item intercepts), in line with e.g. Fischer and Fontaine 2011; Putnick and Bornstein 2016) in Amos 24.0. We compared male and female teachers with presumption that the structure of the Motivations and Beliefs scales for the two groups would not differ.

After examining factorial structure of the FIT-Choice scale, its known-groups validity was explored. MANOVAs were applied to test for already internationally demonstrated differences in motivations and beliefs between Serbian pre-service class teachers, Social science and Humanities and Science and Engineering subject teachers (e.g. Glutsch and König 2019). Educational trajectories and disciplines and gender were independent variables, while 12 factors for Motivations and six factors for Beliefs served as dependent variables. Descriptive statistics for the entire sample and subgroups were performed, and Bonferroni post hoc tests were used for group comparisons.

\section{Results}

\subsection{Model Testing - Factorial Validity and Reliability}

\section{Motivations for Teaching}

CFA for the 12 motivations, as postulated by Watt and Richardson (2007) yielded somewhat unsatisfactory global fit indices (see Table 2). Therefore, we performed an explanatory factor analysis (EFA), using Maximum likelihood extraction, Direct Oblimin rotation and specifying 12 factors, (like Fokkens-Bruinsma and Canrinus 2012). KMO value of .884 verified the sampling 
adequacy for the EFA. This model explained $65.14 \%$ of the variance. Five cross-loading items were registered (B7 from Intrinsic value, B8 from Job transferability, B29 from Time for family, B39 from Prior T\&L experiences, and B53 from the Shape future of children factor), and subsequently deleted. A CFA with five omitted items was performed and the obtained model-fit proved to be very good (see Table 2).

\section{Insert Table 2}

For further analysis, we opted for the adjusted 12-factor model, because it fits the data better than the original model and still highly corresponds to the theory. This model replicated 10 original factors (Watt and Richardson 2008; see Table 4 and Appendix A), added one factor postulated in the first model version-Bludging (Watt and Richardson 2007), and yielded one new factor. Cronbach alpha coefficients of internal consistency for all 12 subscales were good, ranging from .685 to .923 (see Table 4). Correlations among 12 latent motivation factors are presented in Table B1 in Appendix B.

\section{Beliefs about Teaching}

The CFA for six perceptions and beliefs factors yielded acceptable global fit indices (see Table 3). Like for Motivations, the same EFA was performed with six fixed factors. One item's (C14 for Expert career) loading proved to be low (.29), and it was subsequently removed. The EFA without that item showed KMO value of .788 and yielded six factors explaining $62.21 \%$ variance. A CFA for the adjusted six factors yielded slightly better results (see Table 3), so we relied on the adjusted model for further analyses.

\section{Insert Table 3}


The internal reliability of the scale proved to be acceptable (see Table 4). Cronbach alpha for the subscale Expert career was poor $(\alpha=.441)$, so subsequent analyses were performed without this scale. The correlations between five latent belief factors are presented in the Table B2 in Appendix B.

\section{Insert Table 4}

\subsection{Invariance Testing}

We tested three levels of measurement invariance across genders (see Table 5 for Motivations and Table 6 for Beliefs), with the unconstrained (adjusted 12-factor) model representing a baseline model against which subsequent models were compared. From the Table 5 we can see that the three models are not significantly worse than the baseline model.

\section{Insert Table 5}

Metric $\left(\Delta \chi^{2}=20.521, \mathrm{df}=21, \mathrm{p}=.488\right)$ and scalar $\left(\Delta \chi^{2}=68.589, \mathrm{df}=78, \mathrm{p}=.768\right)$ invariance for the Factors influencing choice of a teaching career scale were established comparing to the baseline (unconstrained model).

As for Beliefs, it was found that the three models fit the data in a similar way as the baseline unconstrained (adjusted 6-factor) model (see Table 6). Model comparison showed that metric and scalar models were satisfied $\left(\Delta \chi^{2}=19.359, \mathrm{df}=13, \mathrm{p}=.317\right.$ and $\Delta \chi^{2}=25.566, \mathrm{df}=$ $21, \mathrm{p}=.223$, respectively). Somewhat lower NFI for both Motivations and Beliefs might be explained by the sample size of the groups (Ullman 2001).

\section{Insert Table 6}




\subsection{Serbian Teachers' Motivation and Beliefs about the Teaching Profession and Groups Comparison - Known-Groups Validity}

The highest rated reason for choosing a teaching career among Serbian pre-service teachers was Intrinsic value $(M=6.14)$. Mean scores for Personal utility value, including Bludging, and Social utility value were 4.12 and 5.37, respectively, while Fallback career was the lowest ranked factor. The participants were on average satisfied with their career choice $(M=5.47)$, although the Task demand $(M=5.82)$ and Task return $(M=3.19)$ ratio proved to be unfavourable (see Table 7). Descriptives for the three groups based on educational trajectories and disciplines yielded somewhat different results, mostly regarding the Motivations (see Table 7).

\section{Insert Table 7}

There were multivariate effects of educational trajectories and disciplines (Pillai's Trace $=.175$, $\left.F(12,412)=3.305, p=.000, \eta_{p}{ }^{2}=.088\right)$ and gender (Pillai's Trace $=.089, F(12,412)=3.346$, $\left.p=.000, \eta_{p}^{2}=.089\right)$ for the Motivations, while multivariate interaction was non-significant (Pillai's Trace $\left.=.042, F(24,826)=0.733, p=.820, \eta_{p}{ }^{2}=.021\right)$. There were no significant univariate interactions between gender and educational trajectories and disciplines, so we proceeded with the analyses of their main effects.

Following Bonferroni correction, only one gender difference remained significant female students reported higher values on Working with children and adolescents compared to males $(p=.003)$, with the effect size being small $\left(\eta_{p}^{2}=.021\right)$. Based on their educational trajectories and disciplines, omnibus tests revealed that prospective teachers significantly differ on the following factors: Working with children/adolescents $\left(F(2,430)=10.226, p=.000, \eta_{p}{ }^{2}=\right.$ $.045)$, Enhance social equity $\left(F(2,430)=6.706, p=.001, \eta_{p}{ }^{2}=.030\right)$, Time for family $(F(2,430)$ 
$\left.=8.148, p=.000, \eta_{p}{ }^{2}=.037\right)$ and Transferability and Security $\left(F(2,430)=7.161, p=.001, \eta_{p}{ }^{2}\right.$ $=.032$ ). Post hoc tests showed that prospective class teachers scored significantly higher than both groups of prospective subject teachers on Work with children/adolescents ( $p_{\text {Social }}=.000$, $\left.\mathrm{p}_{\text {Science }}=038\right)$ as well as on Enhance social equity $\left(p_{\text {Social }}=.017, p_{\text {Science }}=001\right)$; they also proved to be more strongly motivated by Shape future of children than the prospective Science and Engineering teachers $\left(p_{\text {Science }}=.015\right)$. Students from Social Science and Humanities faculties had lower scores compared to other groups on two factors: Time for family $\left(p_{\text {Class }}=.004, p_{\text {Science }}=\right.$ $.002)$ and Transferability and Security $\left(p_{\text {Class }}=.035, p_{\text {Science }}=.001\right)$.

MANOVA for the Beliefs about teaching showed multivariate effects of educational trajectories and disciplines (Pillai's Trace $\left.=.084, F(12,838)=3.078, p=.000, \eta_{p}{ }^{2}=.088\right)$ and gender (Pillai's Trace $=.0 .046, F(6,418)=3.383, p=.003, \eta_{p}^{2}=.042$ ), while multivariate interaction was again non-significant (Pillai's Trace $=.023, F(12,838)=0.803, p=.648, \eta_{p}{ }^{2}=$ $.011)$.

After using Bonferroni correction, one significant gender difference appeared - females scored higher on High demand scale than males $\left(p=.000, \eta_{p}{ }^{2}=.041\right)$. Omnibus univariate tests for educational trajectories and disciplines revealed differences on Satisfaction with career choice and High demand factor. Subsequent post-hoc tests showed that future class teachers reported higher satisfaction with their career choice compared to prospective subject teachers $\left(p_{\text {Social }}=.001, p_{\text {Science }}=.003\right)$ and experienced significantly less social discouragement than students in Social Science and Humanities $\left(p_{\text {Social }}=.046\right)$. Students in the Science and Engineering field evaluated the teaching profession as less demanding than both other student groups $\left(p_{\text {Class }}=.000, p_{\text {Social }}=.054\right)$. 


\section{Discussion}

The authors strove to gain a deeper understanding of the Serbian pre-service teachers' motivation for the teaching profession by relying on a well-established and parsimonious theoretical model. Our first aim was to validate the FIT-Choice scale in the Serbian context (Watt and Richardson 2007) and to test measurement invariance across genders. The second aim was to determine prospective teachers' motivations and beliefs about the teaching profession and compare them between different groups of teachers, based on their gender and educational trajectories and disciplines.

\subsection{Structural Validation of the FIT-Choice Scale, Reliability and Measurement Invariance}

After the deletion of five items due to factor cross-loadings, a 12-factors model, similar to those proposed by Watt and Richardson (2007), demonstrated a good fit. Six original factors were entirely replicated, and four were replicated with the removal of one item per factor. In terms of differences, Bludging appeared as a separate factor from Time for family, and Job security and Transferability merged into one factor. Bludging and Time for family being separate is in line with the first version of the theoretical model (see Watt and Richardson 2007). Empirical merging of Job security and Transferability is theoretically defensible, given that both are included in the same higher-order factor - Extrinsic motivation, and given that Transferability has already proven to be irrelevant in certain contexts (Watt et al. 2012). We assume that Transferability appeared less relevant in the Serbian context due to low career mobility of Serbian teachers and low levels of cooperation with international partners, giving them poor chances to find teaching positions outside of Serbia (Kovács-Cerovic 2006). Similar findings were reported in Croatia (Jugović et al. 2012), suggesting that this subscale should be carefully 
interpreted in the countries where teachers do not have internationally recognisable qualifications. The reliability of the entire scale was high, with only Fallback career demonstrating a low reliability coefficient, which is in line with previous studies (Goller et al. 2019; Kilinç, Watt, and Richardson 2012; Watt et al. 2012). Moreover, the basic organization of the construct Motivations was supported among male and female prospective teachers, and the loadings and intercepts were equivalent across groups.

A six-factor model for the Beliefs/Perceptions about teaching (with one item removed) fit the data well; however, the Expert career scale demonstrated very poor reliability. Although carefully translated, we believe that this scale's items were not sufficiently clear to our participants, who might understand expert knowledge, didactics and subject didactics skills differently from how they are defined in theory. This can be attributed to the quality of teacher education (Simić 2014), where some prospective subject teachers attend only a few college courses for developing their teaching competences. Like for Motivations, we proved the psychometric equivalence of the construct Beliefs across genders.

\subsection{Teaching Motivations and Beliefs about Teaching in Serbia and Known-Group Validation}

Serbian pre-service teachers had the highest motivation scores for Intrinsic career value, followed by Social utility value and Perceived teaching ability, while the lowest scores were on Personal utility value and Fallback career. This means that Serbian prospective teachers choose the teaching career because of their love for teaching and working with youth, which they believe can lead towards making a wider social contribution, while the job security and shorter working hours are less valued. As for Socialization influences, prior teaching and learning 
experiences had a strong impact on career choice, suggesting the importance of good teacher role models, while the influences of significant others were low.

These results match previous findings on motivation for choosing the teaching profession of Serbian pre-service and in-service teachers (Marušić Jablanović 2014; Simić 2015; Simić, Bogdanović, and Jovanović 2013). They are also in accordance with results obtained in Croatia (Jugović et al. 2012). The profile of the pre-service teachers' motivations in Serbia was more alike to the profile of their peers from Western countries (see Watt et al. 2012), than those from Turkey or China (see Kilinç, Watt, and Richardson 2012; Liu and Qi 2006). This could be attributed to Serbia's strong inclination towards the European Union with the beginning of democratic changes in 2000, which resulted in young people (particularly those college educated and living in urban areas) being EU-oriented and adhering to values promoted in Western countries (Popadić, Pavlović, and Mihailović 2019; Tomanović and Stanojević 2015).

As for Beliefs about teaching, our participants perceive teaching as a demanding career with moderate social status. These findings are in accordance with previous studies with Serbian teachers, indicating major dissatisfaction with the imbalance between levels of autonomy and status in society, on the one hand, and amount of administrative work and other requirements, on the other (OECD 2013; Pantić and Čekić Marković 2012; Simić 2015). Findings on perceptions of the teaching profession are also in line with those obtained in Turkey, Australia, USA and Germany (see Watt et al. 2012). The difference is that Serbian prospective teachers clearly consider teachers' income more unfavourable than pre-service teachers from other countries where FIT-Choice was applied (see Kilinç, Watt, and Richardson 2012; Watt et al. 2012); their perceptions match those of teachers from Ghana (Salifu, Alagbela, and Ofori 2017). This can be explained by the fact that in Serbia, average teacher salaries were below the state average salary 
at the time of research (European Commission 2018; OECD 2016). Despite this, our respondents expressed greater satisfaction with their career choice than those from Turkey and China, though somewhat lower than pre-service teachers from Croatia and Germany, and much lower than their peers from Australia and the USA. This could be explained by differences in overall socioeconomic situation, and to a certain extent, by slight differences in the sample structures (for example, in the Croatian study, only class teachers were included).

It was confirmed that female students are more enthusiastic about working with children (Müller, Alliata, and Benninghof 2009; Sinclair 2008). This can be explained through internalized traditional beliefs about gender roles that are particularly influential in Serbian society, specifically that females are more caring and competent to work with children (Pešić 2006). However, they perceived teaching as a more demanding job than their male counterparts, probably due to their traditional orientation towards raising children, which makes females more aware of the demands, subsequently having higher expectations of themselves. In line with dominant social values and expectations, we can also assume that females anticipate stronger conflict between work and family roles, and consequently perceive the future job as more demanding. Prospective class teachers were more altruistically motivated and reported higher career choice satisfaction than prospective subject teachers. Although the system requires preservice subject teachers to have pedagogical preparation, their motivation for choosing a teaching career is clearly less altruistic and child-centred than the motivation of pre-service class teachers. This can be explained by different value priorities, with a higher rating of universalism and benevolence values among the prospective class teachers (Marušić Jablanović 2018). Another interpretation is that different pathways of professionalization, leading to different processes of identity formation, are responsible for this difference. Due to the organization of 
their pre-service education and various career opportunities, we can expect that academic subidentity or the identity of the subject matter expert, as proposed by Beijaard, Verloop, and Vermunt (2000), takes precedence over the pedagogical and didactical sub-identities in the majority of subject teachers.

\section{Conclusions and Implications for Teacher Education}

Given that the deviations from the FIT-Choice scale's (Watt and Richardson 2008) factor structure determined in our study had already been recognized elsewhere (e.g. Kilinç, Watt, and Richardson 2012) and are theoretically justifiable (Watt \& Richardson 2007), we concluded that the Serbian version of the FIT-Choice scale has an acceptable structural and known-groups validity and reliability. Only the Expert career scale should be reformulated to contain fewer technical terms and more descriptions of teachers' behaviour and skills. When used in countries with low teacher career mobility and internationally unrecognized teacher qualifications, the Transferability items should either be reformulated to correspond better to the participants' experience and opportunities, or the subscale determined in this study that merges Security and Transferability should be applied.

The motivations for teaching and perceptions of the teaching profession in Serbia are more similar to those in Western European countries, than they are to Turkey or China. The current study suggests that despite (maybe - indeed because of) the unfavourable socioeconomic situation, Serbian prospective teachers are driven by a desire to teach, work with children and contribute to their better future. Strong intrinsic and altruistic motivations might account for the greater satisfaction with career choice than in Turkey and China, despite the unsatisfactory wages and low status of the teaching profession in Serbia. This might reflect their somewhat 
idealized view of the profession (primarily - with direct interaction with students), a phenomenon already recognized in the Serbian context (see e.g. Simić, Jokić, and Vukelić 2017; Simić 2014). Therefore, we recommend providing pre-service teachers with more opportunities for school practice and more mentor support, which could prevent "reality shock" (Veenman 1984) once they enter schools. We also recommend more continuous support, starting from initial teacher education, in improving coping mechanisms that can prevent burnout. Intellectually fulfilled, enthusiastic but realistic teachers would in turn represent great role models to their students and consequently motivate some of them to become teachers, as we saw that prior school experience played an important role in choosing a teaching career.

Knowing that intrinsic and altruistic motivations are related to a more favourable job attitude and smaller attrition intentions (Simić 2015), we can expect different behavioural patterns and career cycles of class and subject teachers. With fewer possibilities for finding a career elsewhere, and motivated mostly by Intrinsic value, Social utility value and Social influences, class teachers are expected to be more devoted and satisfied with their job, like highly engaged "persisters", a category recognized by Watt and Richardson (2008). Subject teachers, and particularly those in Science and Engineering, being more motivated by Job transferability and Security and less by altruistic motives than the other groups of pre-service teachers can be considered similar to "low engaged desisters" (Watt and Richardson 2008). Therefore, they might need even more psychological support during their studies, and their initial education should involve more psychological and pedagogical courses and school practice than it currently does. Given that initial teacher education proved to be the main generator of teacher professional identity (Vranješević and Vujisić-Živković 2013), in the case of both groups of pre-service subject teachers it should involve more reflection on the relationship between personal and 
professional identity and support the development of those aspects of identity that are related to "being a teacher" rather than "being a subject matter expert”. This should include ,know-what" knowledge regarding professional roles or sub-identities that a modern teacher is expected to assume (e.g. reflexive practicioner, interculturally sensitive teacher, leader etc.), as well as „know-how“ knowledge that provides them with practical tools for developing these roles and enacting them in the classroom. We would also recommend more professional and psychological support during the induction period, although one might expect them to fluctuate when opportunities to work in IT, bank, pharmacy etc. appear.

Finally, we can suggest using the FIT-Choice scale in the process of professional selection, career guidance and professional coaching of pre- and in-service teachers, where it can be used as both assessment and self-assessment tool.

\section{Limitations}

For the model to have a good fit, five items were removed from the Motivations for teaching scale, which resulted in having five factors with only two items. However, two-item subscales have been acknowledged in many studies applying the FIT-Choice scale (see e.g. Jugović et al. 2012; Kilinç, Watt, and Richardson 2012). The Expert career and the Transferability subscales proved to be more context-dependent than other subscales, so the future studies need to take into account some sociocultural-specific issues, such as teacher mobility and the characteristics of initial teacher education. 


\section{Acknowledgements}

We thank Professor Dr Helen Watt for sharing the original FIT-choice questionnaire with us and for providing us support with the instrument translation and scores calculation.

\section{Funding}

This research was funded by the Ministry of Education, Science and Technological Development of the Republic of Serbia (Project with the Contract No. 451-03-9/2021-14/200018, and the Project number 179018).

\section{Disclosure statement}

No potential competing interest was reported by the authors.

\section{References}

Beijaard, D., Verloop, N., and Vermunt, J. D. 2000. "Teachers' Perceptions of Professional Identity: An Exploratory Study from a Personal Knowledge Perspective.” Teaching and Teacher Education 16: 749-764.

Cooper, J. M., and Alvarado, A. 2006. Preparation, Recruitment and Retention of Teachers. UNESCO Education Policy Series No. 5. Paris: The International Institute for Educational Planning (IIEP) \& Brussels: The International Academy of Education (IAE).

Eccles, J. S. 2005. "Subjective Task Value and the Eccles et al. Model of Achievement-Related Choices”. In Handbook of Competence and Motivation, edited by A. J. Elliot, and C. S. Dweck, 105-121. New York, NY: The Guilford Press. 
European Commission/EACEA/Eurydice. 2018. Teachers' and School Heads' Salaries and Allowances in Europe - 2016/17. Eurydice Facts and Figures. Luxembourg: Publications Office of the European Union.

Fischer, R., and Fontaine, J. R. J. 2011. "Methods for investigating structural equivalence.” In Culture and Psychology. Cross-Cultural Research Methods in Psychology, edited by D. Matsumoto, and F. J. R. van de Vijver, 179-215. Cambridge University Press.

Fokkens-Bruinsma, M., and Canrinus, E. T. 2012. "The Factors Influencing Teaching (FIT)Choice Scale in a Dutch Teacher Education Program.” Asia-Pacific Journal of Teacher Education 40 (3): 249-269. https://doi.org/10.1080/1359866X.2012.700043.

Glutsch, N., and König, J. 2019. “Pre-service Teachers' Motivations for Choosing Teaching as a Career: Does Subject Interest Matter?” Journal of Education for Teaching 45 (5): 494-510. doi: 10.1080/02607476.2019.1674560.

Goller, M., Ursin, J., Vähäsantanen, K., Festner, D., and Harteis, C. 2019. "Finnish and German Student Teachers' Motivations for Choosing Teaching as a Career. The First Application of the FIT-Choice Scale in Finland." Teaching and Teacher Education 85: 235-248. https://doi.org/10.1016/j.tate.2019.06.023.

Government of the Republic of Serbia. 2018. "Third National Report on Social Inclusion and Poverty Reduction in the Republic of Serbia.” Belgrade: Government of the Republic of Serbia.

Hofstede, G., Hofstede, G. J., and Minkov, M. 2005. Cultures and Organizations: Software of the Mind. McGraw-Hill. http://dx.doi.org/10.1080/1359866X.2012.700048. 
Jeon, L., and Wells, M. B. 2018. “An Organizational-Level Analysis of Early Childhood Teachers' Job Attitudes: Workplace Satisfaction Affects Early Head Start and Head Start Teacher Turnover." Child \& Youth Care Forum 47 (4): 563-581.

Jovanović, O. Bogdanović, S., and Simić. N. 2013. "Zašto želim da budem nastavnik? Struktura motivacije studenata nastavničkih fakulteta za posao nastavnika" [Why Teaching? Preservice Teachers' Structure of Motivation for a Teaching Profession] in Zbornik radova sa XIX naučnog skupa Empirijska istraživanja u psihologiji, 295-300.

Beograd: Filozofski fakultet.

Jugović, I., Marušić, I., Pavin Ivanec, T., and Vizek Vidović, V. 2012. "Motivation and Personality of Preservice Teachers in Croatia." Asia-Pacific Journal of Teacher Education 40 (3): 271-287. http://dx.doi.org/10.1080/1359866X.2012.700044.

Keller, M. M., Neumann, K., and Fisher, H. E. 2017. “The Impact of Physics Teachers’ Pedagogical Content Knowledge and Motivation on Students’ Achievement and Interest.” Journal of Research in Science Teaching 54 (5): 586-614. doi: 10.1002/tea.21378.

Kılınç, A., Watt, H. M. G., and Richardson, P. W. 2012. "Factors Influencing Teaching Choice in Turkey.” Asia-Pacific Journal of Teacher Education 40 (3): 199-226.

Kovács-Cerovic, T. 2006. "National Report: Serbia". In The prospects of Teacher Education in South East Europe, edited by P. Zgaga, 487-526. Ljubljana, Slovenia: Centre for Educational Policy Studies, Pedagogical faculty, University of Ljubljana.

Lazić, M., and Cvejić, S. 2007. "Class and Values in Post-Socialist Transformation in Serbia." International Journal of Sociology, 37 (3): 54-74. doi: 10.2753/IJS0020-7659370300.

Lin, E., Shia, Q., Wang, J., Zhang, S., and Hui, L. 2012. "Initial Motivations for Teaching: Comparison between Preservice Teachers in the United States and China." Asia-Pacific 
Journal of Teacher Education 40 (3): 227-248.

https://doi.org/10.1080/1359866X.2012.700047.

Liu, P., and Qi, C. 2006. "Examining Teacher Preparation in P.R. China and the U.S.: A

Preliminary Comparative Study.” International Education 35 (2): 5-26.

Manić, I. 2017. "Vrednosne orijentacije i porodične vrednosti mladih u Srbiji“ [Value

Orientations and Family Values of Youth in Serbia]. Published doctoral thesis. University of Niš, Serbia.

Marušić Jablanović, M. 2014. "Da li je intrinzička motivacija profesionalnog izbora značajna za kasniji profesionalni razvoj nastavnika?“ [Is Intrinsic Motivation for Teaching Important for Future Professional Development?] Psihologija 47 (4): 449-464. doi:

10.2298/PSI1404449M.

Marušić Jablanović, M. 2018. "Value Priorities of Future Preschool and Class Teachers in Serbia in Terms of the Schwartz Refined Value Theory.” Psihologija 51 (2): 143-161. https://doi.org/10.2298/PSI160902013M.

Marušić Jablanović, M., and Vračar, S. 2019. "Ispitivanje motivacije nastavnika iz Srbije za izbor zanimanja primenom FIT-Choice skale" [Exploring Serbian Teachers' Motivation for Teaching with the Application of FIT-Choice Scale] Zbornik Instituta za pedagoška istraživanja 51 (1): 7-45. https://doi.org/10.2298/ZIPI1901007M.

Marušić, I., Jugović, I., and Pavin Ivanec, T. 2011. "Primjena teorije vrijednosti i očekivanja u kontekstu odabira učiteljske profesije" [Application of the Expectancy-Value Theory in Choosing a Teaching Career]. Psihologijske teme 20 (2): 299-318. 
Marušić, M., and Oikonomou, M. 2013. "Value Hierarchy of Future Subject Teachers in Serbia in the Context of Schwartz Theory." Zbornik Instituta za pedagoška istraživanja 45 (2): $241-259$.

Müller, K., Alliata, R., and Benninghof, F. 2009. "Attracting and Retaining Teachers - a Question of Motivation.” Educational Management Administration \& Leadership 37 (5): 574-599. doi: 10.1177/1741143209339651.

Nišević, S., and Colić, V. 2010. "Profesionalni status, zadovoljstvo poslom i stručni profil vaspitača i učitelja” [Professional Status, Job Satisfaction and Vocational Profile of Kindergarten and Elementary School Teachers]. Nastava i vaspitanje, 59 (2). 314-325.

OECD. 2013. Education at a Glance 2013: OECD Indicators. Paris: OECD Publishing. http://dx.doi.org/10.1787/eag-2013-en.

OECD. 2014. TALIS 2013 Results: An International Perspective on Teaching and Learning. Paris: OECD Publishing. https://doi.org/10.1787/9789264196261-en.

OECD. 2016. Education at a Glance 2016: OECD Indicators. Paris: OECD Publishing. http://dx.doi.org/10.187/eag-2016-en.

Pantić, N., and Čekic Markovic, J. 2012. Teachers in Serbia: Attitudes towards the Profession and Reforms in Education. Belgrade: Centre for Education Policy.

Pešić, J. 2006. "Persistence of Traditionalist Value Orientations in Serbia." Sociologija 48 (4): 289-307.

Popadić, D., Pavlović, Z., and Mihailović, S. 2019. Mladi u Srbiji 2018/2019 [Young People in Serbia 2018/2019]. Belgrade: Friedrich-Ebert Stiftung. 
Putnick, D. L., and Bornstein, M. H. 2016. "Measurement Invariance Conventions and Reporting: The State of the Art and Future Directions for Psychological Research.” Developmental Review 41: 71-90. doi: 10.1016/j.dr.2016.06.004.

Richardson, P. W., and Watt, H. M. G. 2006. "Who Chooses Teaching and Why? Profiling Characteristics and Motivations across Three Australian Universities." Asia-Pacific Journal of Teacher Education 34 (1): 27-56.

Salifu, I., Alagbela, A. A., and Ofori, C. G. 2018. "Factors Influencing Teaching as a Career Choice (FIT-Choice) in Ghana." Teaching Education 29 (2): 111-134. doi: 10.1080/ 10476210.2017. 1365360 .

Schafer, J. L., and Graham, J. W. 2002. "Missing Data: Our View of the State of the Art." Psychological Methods 7 (2): 147-177. doi:10.1037/1082-989X.7.2.147.

Simić, N. 2014. "Nastavničke brige i načini njihovog prevazilaženja." Doktorska disertacija. [“Teacher Concerns and Coping Mechanisms.” Phd Diss.]. Beograd: Filozofski fakultet.

Simić, N. 2015. "Motivacija za izbor profesije nastavnik - Perspektiva budućih nastavnika, pripravnika $\mathrm{i}$ iskusnih predmetnih nastavnika.” [Motivation for a Teaching Profession Perspective of Prospective Teacher, Novices and Experienced Subject Teachers] Zbornik Instituta za pedagoška istraživanja 47 (1): 199-221. doi: 10.2298/ZIPI1502199S.

Simić, N. 2019. Profesionalne brige nastavnika [Teacher Professional Concerns]. Beograd: Institut za psihologiju, Filozofski fakultet.

Simić, N., Jokić, T., and Vukelić, M. 2017. "Personal Construct Psychology in Preservice Teacher Education: The Path Toward Reflexivity." Journal of Constructivist Psychology 1-17, https://doi.org/10.1080/10720537.2017.1336137. 
Simić, N., Purić, D., and Stančić, M. 2018. "Motivation for the Teaching Profession: Evaluation of the Orientation for Teaching Survey on In-service Teachers." Psihologija 51 (3): 309331. https://doi.org/10.2298/PSI170327012S.

Simić, N., Toković, M., and Đorđević, V. 2019. “Zadovoljstvo poslom naučnica u kontekstu postsocijalističke transformacije Srbije” [Job Satisfaction of Female Scientists in The Context of Postsocialist Transformation in Serbia]. Etnoantropološki problemi 14 (1): 297-323. https://doi.org/10.21301/eap.v14i1.12.

Sinclair, C. 2008. "Initial and Changing Student Teacher Motivation and Commitment to Teaching.” Asia-Pacific Journal of Teacher Education 36 (2): 79-104. doi: 10.1080/13598660801971658.

Skaalvik, E. M., and Skaalvik, S. 2011. "Teacher Job Satisfaction and Motivation to Leave the Teaching Profession: Relations with School Context, Feeling of Belonging,aAnd Emotional Exhaustion.” Teaching and Teacher Education 27 (6): 1029-1038.

Skočajić, T. 2017. “Analiza podataka o nastavnicima u osnovnom i srednjem obrazovanju demografski podaci, zapošljavanje, napuštanje profesije" [Analysis of Data Concerning Teachers in Elementary and Secondary Education, Demographic Data, Employment and Turnover]. In Dijalozi u obrazovanju 2017, Zbornik radova [Dialogs in Education 2017, Book of Proceedings], edited by D. Pavlović-Babić, O. Jovanović, and N. Simić, 10-33. Beograd: Društvo istraživača u obrazovanju u Srbiji.

Stanković, D. 2011. “Obrazovne promene u Srbiji (2000-2010)“ [Educational Changes in Serbia 2000-2010). In Predstave o obrazovnim promenama u Srbiji [Perceptions of Educational Changes in Serbia], edited by M. Vujačić, J. Pavlović, D. Stanković, V. Džinović, and I. Đerić, 31-60. Beograd: Institut za pedagoška istraživanja. 
Tomanović, S., and Stanojević, D. 2015. Mladi u Srbiji. Stanja, opažanja, verovanja i nadanja. [Youth in Serbia. States, Perceptions, Beliefs and Hopes]. Belgrade: Friedrich Ebert Stiftung \& SeConSgrupa za razvojnu inicijativu.

Ullman, J. B. 2001. "Structural Equation Modeling.” In Using Multivariate Statistics, edited by B. G. Tabachnick, and L. S. Fidell, 653-771. Needham Heights, MA: Allyn \& Bacon. Veenman, S. 1984. "Perceived Problems of Beginning Teachers." Review of Educational Research 54 (2): 143-178.

Videnović, M., and Čaprić, G. 2020. PISA 2018: Izveštaj za Republiku Srbiju [PISA report for the Republic of Serbia]. Beograd: Ministarstvo prosvete, nauke i tehnološkog razvoja. Vranješević, J., and Vujisić-Živković, N. 2013. „Profesionalni identitet nastavnika i obrazovanje između kompetencija i ideala" [Teacher Professional Identity and Education, between Competencies and Ideals]. Teme, 37 (2): 581-594.

Watt, H. M. G., and Richardson, P. 2007. "Motivational Factors Influencing Teaching as Career Choice: Development and Validation of the FIT-Choice Scale." The Journal of Experimental Education 75 (3): 167-202. https://doi.org/10.3200/JEXE.75.3.167-202.

Watt, H. M. G., and Richardson, P. W. 2008. "Motivations, Perceptions, and Aspirations Concerning Teaching as a Career for Different Types of Beginning Teachers." Learning and Instruction 18 (5): 408-428. doi:10.1016/j.learninstruc.2008.06.002.

Watt, H. M. G., Richardson, P. W., Klusmann, U., Kunter, M., Beyer, B., Trautwein, U., and Baumert, J. 2012. “Motivations for Choosing Teaching as a Career: An international Comparison Using the FIT-Choice Scale.” Teaching and Teacher Education 28: 791805. doi:10.1016/j.tate.2012.03.003. 
Yüce, K., Şahin, E., and Koçer, Ö. 2013. "Motivations for Choosing Teaching as a Career: A Perspective of Pre-service Teachers from a Turkish Context." Asia Pacific Education Review 14 (3): 295-306. doi: 10.1007/s12564-013-9258-9. 